\title{
Oxidoreduktáz enzimek bioutánzó reakcióinak vizsgálata
}

\author{
LAKK-BOGÁTH Dóra*, KAIZER József * \\ Pannon Egyetem, TTK, Bioszerves és Biokoordinációs Kémia Kutatócsoport, \\ Wartha Vince utca 1, 8200, Veszprém, Magyarország
}

\section{Bevezetés}

Mind a kémia, mind a biológia területén régóta kutatják már a metalloenzimek által katalizált reakciók mechanizmusát. A szervezetből nehéz, bonyolult eljárással lehet kinyerni az enzimeket, amelyek tisztasága sem mindig kielégítő. Az aktív centrum szerkezete a legtöbb esetben még nem ismert, ezen problémák kiküszöbölésére a szintetikus modellezés egy jól bevált módszer. Az enzimmodellek alapvetően két csoportba sorolhatók: szerkezeti- és müködési (funkcionális) modellek [1]. A szerkezeti modellek az aktív centrum térbeli szerkezetének megismerését segítik elő a modellek és az enzimek spektroszkópiai adatainak összehasonlításával. A múködési modellek segítik az enzimkatalizált reakciók mechanizmusának megértését és lehetővé teszik a mesterséges katalitikus rendszerek kidolgozását.

\section{Egymagvú vastartalmú modellek}

Az egy- és kétmagvú nem-hem vastartalmú enzimek legnagyobb és legváltozatosabb családját alkotják az $\alpha$-ketosavat $(\alpha-\mathrm{KG})$ koszubsztrátumként tartalmazó enzimek, amelyek aktív centrumai az 1. Ábrán láthatóak. Ezen enzimek számos átalakítást képesek elvégezni, pl.: hidroxilezést, deszaturációt, epimerizációt, heterociklusos gyűrüképződést és gyűrükapcsolást, epoxidációt, endoperoxid képződést, valamint halogénezést. Ezek az enzimek szerepet játszanak számos fontos biológiai folyamatban is: a sejtek oxigénérzékelésében [2], a DNS és az RNS javításában [3], epigenetikai szabályozás során a hiszton demetilezésében [4], különböző fehérjék aminosav oldalláncainak poszttranszlációs módosításában [2; 5; 6] és antibiotikumok bioszintézisében [7].

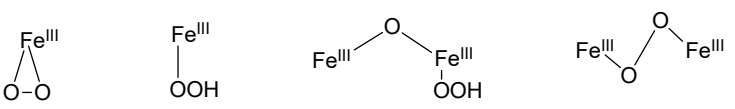

$$
\begin{aligned}
& { }_{0}^{\mathrm{Fe}^{v}} \|_{0}^{\mathrm{Fe}^{\mathrm{IV}}}
\end{aligned}
$$

1. Ábra. Vastartalmú enzimek reaktív intermedierjei

A vastartalmú $\alpha$-KG-függő enzimek leggyakrabban a szubsztrátumok C-H kötésének hidroxilezését katalizálják (2. Ábra). Ilyen enzimek a TauD (taurin-dioxigenáz) (1) és a $\mathrm{P}_{4} \mathrm{H}$ (prolil-4-hidroxiláz) (2), amelyek intermolekuláris dioxigenázok, mivel a vizsgálatok során a jelzett ${ }^{18} \mathrm{O}_{2}$ oxigénatomjai két különböző termékben jelennek meg. A TauD a taurin szulfonátcsoport melletti szénatomjának hidroxilezési reakcióját katalizálja. A hidroxilezett termék aminoacetaldehidre és szulfitra bomlik.

A TauD (1) az első egymagvú, nem-hem vastartalmú enzim, amelyben azonosították az oxovas(IV) (TauD-J) intermediert [8]. Mössbauer spektroszkópiával megállapították, hogy az intermedier nagyspinszámú $(\mathrm{S}=2), 0,30 \mathrm{mms}^{-1}$ izomereltolódással és $0,90 \mathrm{mms}^{-1} \mathrm{kvadrupol-felhasadással}$ rendelkezik [9]. Az EXAFS mérés alapján a Fe-O kötéstávolság 1,62 Å [10]. Deuterált taurinnal végzett megfigyelések alapján kimutatták, hogy a taurin C1-es szénatomjáról hasad le a $\mathrm{H}$, amit a kinetikus izotóp effektus (KIE) érté-

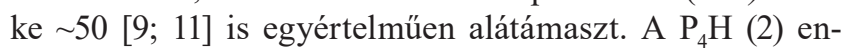
zim esetében is kimutatták az oxovas(IV) intermediert, és meghatározták a Mössbauer paramétereit (izomereltolódás: $0,30 \mathrm{mms}^{-1}$, kvadrupol-felhasadás: $0,82 \mathrm{mms}^{-1}$ ) és a KIE értéket $(\sim 60)$, amelyek nagyon hasonlóak a TauD-J intermedierjére kapott értékekhez [12]. A két különböző szubsztrátummal rendelkező enzim közötti feltűnő hasonlóság azt sugallja, hogy az $\alpha$-KG-függő hidroxilázokra ugyanaz a mechanizmus jellemző.

$$
\text { (1) }
$$
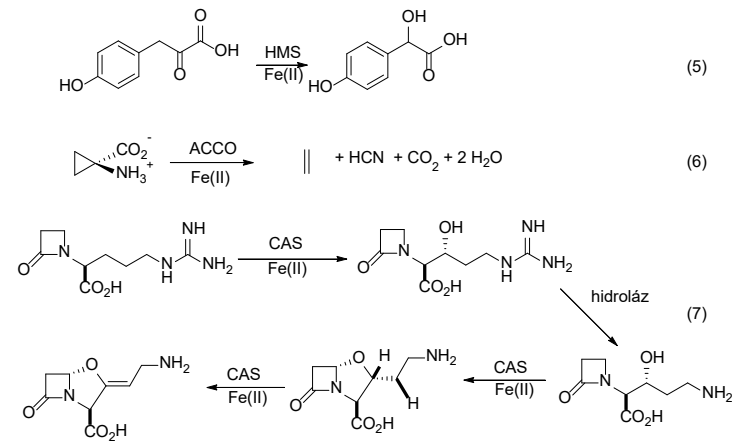

2. Ábra. $\alpha$-ketosav függő oxidoreduktázok

* Tel.: +36 88624 720; e-mail: kaizer@almos.uni-pannon.hu, lakkd@almos.uni-pannon.hu 
A klavaminát szintáz (CAS) (7) és a carbapenem szintáz (CarC) olyan vastartalmú $\alpha$-KG-függő enzimek, amelyek a szubsztrátumok deszaturációját katalizálják. Továbbá a CAS katalizál még hidroxilezést és heterociklusos gyürüképződést, míg a CarC epimerizációt is [13]. A timin hidroxiláz $(\mathrm{TH})(3)$ a nukleinsavak metabolizmusát katalizáló vastartalmú $\alpha-K G$-függő enzim [14]. Az $\alpha$-KG-függő enzimek reaktivitása sokoldalú, ezért nagyon változatos oxidációs reakciókra képesek.

A 4-hidroxifenilpiruvát-dioxigenáz (HPP) (4) enzim által katalizált reakcióban az $\alpha$-keto-karboxilát oxidatív dekarboxilezését a fenilgyürü hidroxileződése kíséri, valamint egy 1,2-alkil-vándorlás, míg a 4-hidroximandelát-szintáz (HMS) (5) enzim által katalizált reakciókban ehelyett a benzilhelyzetű C-atom hidroxileződése játszódik le [15]. A növényekben az etilén bioszintézisének az utolsó lépése az 1-amino-ciklopropán-1-karbonsav (ACCH) gyürühasítási reakciója, melyet az ACC oxidáz enzim katalizál (6) [15; 16; $17 ; 18]$.
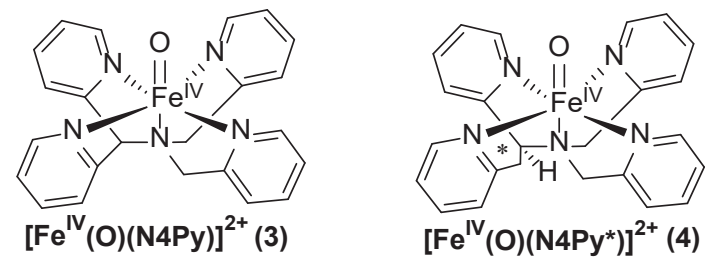

3. Ábra. Az előállított komplexek oxovas(IV) intermedierjei

Az egymagvú nem-hem vastartalmú enzimek modellezésére a következő prekurzor komplexeket és oxovas(IV) intermediereket (3. Ábra) állítottuk elö: [ $\left.\mathrm{Fe}^{\mathrm{II}}(\mathrm{N} 4 \mathrm{Py})\left(\mathrm{CH}_{3} \mathrm{CN}\right)\right]$ $\left(\mathrm{ClO}_{4}\right)_{2}(\mathrm{~N} 4 \mathrm{Py}=N, N$-bisz(2-piridil-metil)-bisz(2-piridil)- metil-amin) (1), $\left[\mathrm{Fe}^{\mathrm{II}}(\mathrm{N} 4 \mathrm{Py} *)\left(\mathrm{CH}_{3} \mathrm{CN}\right)\right]\left(\mathrm{ClO}_{4}\right)_{2}(\mathrm{~N} 4 \mathrm{Py} *=$ $N, N$-bisz(2-piridil-metil)- $N$-bisz(2-piridil)-metil-amin) (2), $\left[\mathrm{Fe}^{\mathrm{IV}}(\mathrm{O})(\mathrm{N} 4 \mathrm{Py})\right]^{2+}(3),\left[\mathrm{Fe}^{\mathrm{IV}}(\mathrm{O})(\mathrm{N} 4 \mathrm{Py} *)\right]^{2+}(\mathbf{4})$.

A komplexek hatékonyságát, reaktivitását vizsgáltuk oxigénatom transzfer (OAT) [19] és hidrogénatom transzfer (HAT) [20,21] reakciókban (4. Ábra), valamint a királis vaskomplexszel enantioszelektív reakciókat dolgoztunk ki. Tioanizol származékok oxidációja során magas enantiomerfelesleg (ee) értékeket sikerült elérnünk (64-96 \%) [22], ciklohexanon származékok Baeyer-Villiger oxidációja során 30-45\%-os [23], etilbenzol oxidációja során 13-33\%-os [24], míg sztirol származékok oxidációja során 8-12\%-os ee értékeket értünk el [25]. (1. Táblázat) Az általunk tanulmányozott $\mathrm{Fe}(\mathrm{IV})$ oxo és Mn(IV)oxo tartalmú komplexek képesek a $\mathrm{H}_{2} \mathrm{O}_{2}$ oxigénné és vízzé történő diszproporcionálódási reakciójára, így azok a nem-hem Fe-tartalmú kataláz enzim modelljeinek is tekinthetők [26-28].

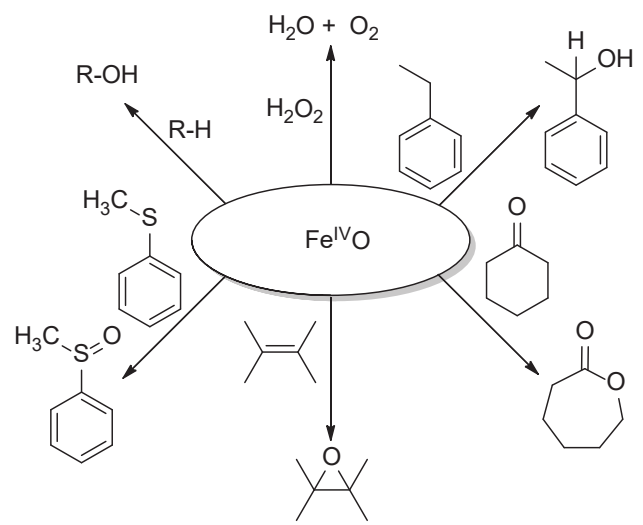

4. Ábra. Oxovas(IV) komplexekkel vizsgált reakciók

\begin{tabular}{|c|c|c|c|c|c|}
\hline & katalizátor & oxidálószer & szubsztrátum & $e e \%$ & Hivatkozás \\
\hline $1^{\mathrm{a}}$ & $(\mathrm{S})-(+)-2$ & $\mathrm{PhIO}$ & 4-metoxi-tioanizol & 95 & {$[22]$} \\
\hline $2^{a}$ & $(\mathrm{R})-(-)-2$ & $\mathrm{PhIO}$ & 4-metoxi-tioanizol & 96 & {$[22]$} \\
\hline $3^{\mathrm{a}}$ & & $(\mathrm{S})-(+)-4$ & 4-metoxi-tioanizol & 84 & {$[22]$} \\
\hline $4^{\mathrm{a}}$ & & $(\mathrm{R})-(-)-4$ & 4-metoxi-tioanizol & 87 & {$[22]$} \\
\hline $5^{b}$ & & $(\mathrm{R})-(-)-4$ & sztirol & 8 & {$[25]$} \\
\hline $6^{\mathrm{b}}$ & & $(\mathrm{R})-(-)-4$ & 4-klór-sztirol & 12 & {$[25]$} \\
\hline $7^{b}$ & & $(\mathrm{R})-(-)-4$ & 4-metil-ciklohexanon & 30 & {$[23]$} \\
\hline $8^{b}$ & & $(\mathrm{R})-(-)-4$ & 4-tercbutil-ciklohexanon & 39 & {$[23]$} \\
\hline $9^{c}$ & $(\mathrm{R})-(-)-2$ & $\mathrm{mCPBA}$ & etilbenzol & 13,4 & {$[24]$} \\
\hline $10^{\mathrm{c}}$ & $(\mathrm{R})-(-)-2$ & $\mathrm{H}_{2} \mathrm{O}_{2}$ & etilbenzol & 12,1 & {$[24]$} \\
\hline $11^{\mathrm{c}}$ & $(\mathrm{R})-(-)-2$ & ТВHP & etilbenzol & 14,4 & {$[24]$} \\
\hline $12^{\mathrm{c}}$ & & $(\mathrm{R})-(-)-4$ & etilbenzol & 33 & {$[24]$} \\
\hline
\end{tabular}

$[\text { katalizátor }]_{0}=6,45 \times 10^{-3} \mathrm{M}$, [szubsztrátum $]_{0}=6,45 \times 10^{-1} \mathrm{M}$, acetonitril oldószerben.

${ }^{a} 35^{\circ} \mathrm{C}$-on elvégzett reakciók. ${ }^{\mathrm{b}} 25^{\circ} \mathrm{C}$-on elvégzett reakciók. ${ }^{\mathrm{c}} 0{ }^{\circ} \mathrm{C}$-on elvégzett reakciók.

1. Táblázat. OAT és HAT reakciók során elért ee értékek 


\section{Flavonoidok}

A flavonoidok kis molekulatömegü, polifenolos fitokémiai anyagok. A növények másodlagos anyagcseréjéből származnak és fontos szerepet játszanak különböző biológiai folyamatokban. Részt vesznek a növények színének kialakításában, UV-védelemben, növényvédelemben, fajok közötti kölcsönhatásban. Széles spektrumú biológiai aktivitásuk miatt szintéziseik a gyógyszervegyészek és a bioszerves kémikusok fontos céljává váltak (5. Ábra) [29].

A flavonok bioszintézisének egyik legfontosabb lépése a flavanonok oxidációja hem és nem-hem vasfüggő enzimekkel. A magas vegyértékü oxovas (IV) intermedierek mind a hem, mind a nem-hem enzimekben kulcsfontosságú oxidánsok, pl: citokróm P450 [30], a flavon-szintáz II (FSII) [31-35], pterin-függő fenilalanin-hidroxiláz [36] és $\alpha$-ketosav-függő dioxigenázok (taurin-dioxigenáz, TauD) [37-39] és flavon-szintáz I, FS I [40-43].

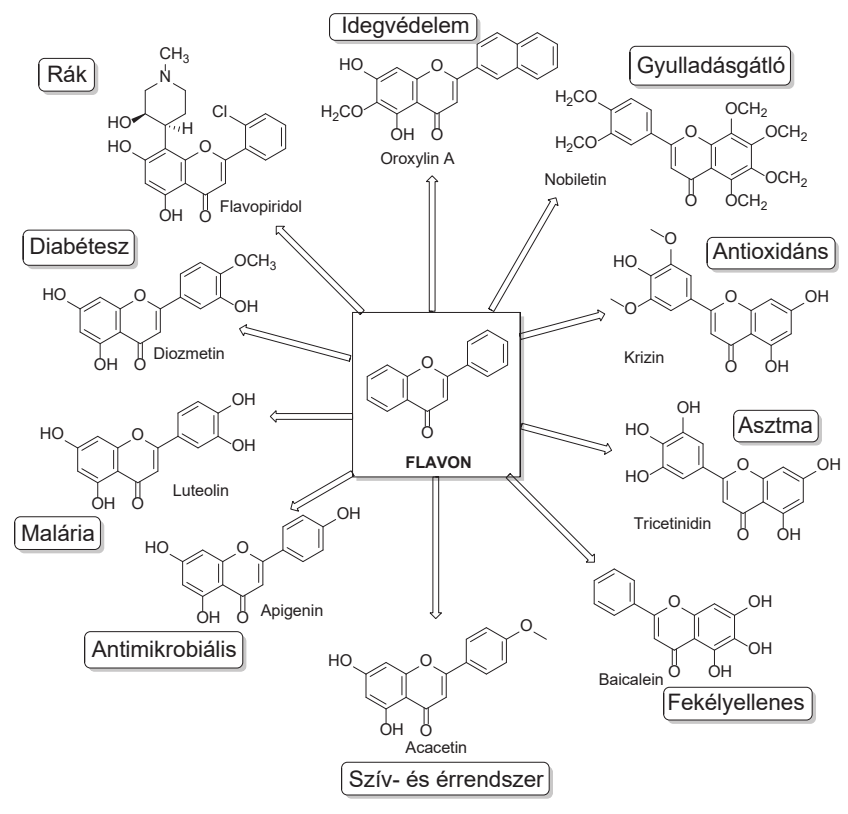

5. Ábra. Flavonok biológiai aktivitása. [29]

A flavanonok bioszintézisét a növényekben két különböző flavon szintáz katalizálja, amelyek teljesen különböző aktív helyekkel és eltérö katalitikus mechanizmusokkal rendelkeznek [40, 44, 45] (6. Ábra). AzFSI-Fe ${ }^{\mathrm{II}} / 2$-oxoglutarátfüggő dioxigenáz hidroxilezés nélkül, hidrogén elvonással, majd 2,3-deszaturációval képzi a flavont.

Az FSII-citokróm P450-függő monooxigenáz katalizálja a feltételezett 2-hidroxi-flavanon kialakulását, majd a dehidratációját, ami flavont eredményez.

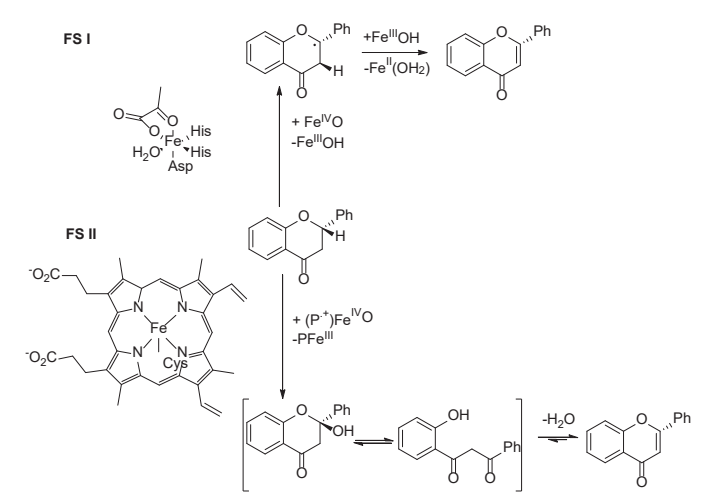

6. Ábra. Flavanon oxidációja hem (FS II) és nem-hem (FS I) flavon szintázzal

Mivel a flavanon egy királis molekula, ezért a racém flavanonok kinetikai rezolválása is elvégezhető királis vastartalmú katalizátorokkal és oxovas(IV) intermedierekkel.

Sztöchiometrikus és katalitikus flavanon oxidációs reakciókat elemeztünk spektroszkópiailag jól jellemzett nemhem Fe(II) és Mn(II) komplexekkel, illetve oxovas(IV) és oxomangán(IV) intermedierekkel (7. Ábra) [46]: $\left[\mathrm{Fe}^{\mathrm{IV}}(\mathrm{O})\right.$ $(\mathrm{Bn}-\mathrm{TPEN})]^{2+}(\mathbf{8})\left(\mathrm{Bn}-\mathrm{TPEN}=N\right.$-benzil- $N, N^{\prime}, N^{\prime}$-trisz $(2-$ piridilmetil)-1,2-diaminoetán) $[47 ; 48], \quad\left[\mathrm{Fe}^{\mathrm{IV}}(\mathrm{O})(\mathrm{CDA}-\right.$ $\left.\left.\mathrm{BPA}^{*}\right)\right]^{2+}(\mathbf{1 3}),\left(\mathrm{CDA}-\mathrm{BPA}=N, N, N^{\prime}, N^{\prime}\right.$ - tetrakisz-(2-piridilmetil)-ciklohexándiamin) $\quad\left[\mathrm{Mn}^{\mathrm{IV}}(\mathrm{O})\left(\mathrm{N}^{2} \mathrm{Py}^{*}\right)\right]^{2+}$ [27], $\left[\mathrm{Mn}^{\mathrm{IV}}(\mathrm{O})(\mathrm{Bn}-\mathrm{TPEN})\right]^{2+}$ (10) [49], [Fe $\mathrm{Fe}^{\mathrm{II}}(\mathrm{Bn}-\mathrm{TPEN})$ $\left.\left(\mathrm{CH}_{3} \mathrm{CN}\right)\right]^{2+}(7),\left[\mathrm{Fe}^{\mathrm{II}}\left(\mathrm{CDA}-\mathrm{BQA}^{*}\right)\right]^{2+}$ (11) $(\mathrm{CDA}-\mathrm{BQA}=$ $N, N, N^{\prime}, N^{\prime}$-tetrakisz-(2-kinolilmetil)-ciklohexándiamin), $\left[\mathrm{Fe}^{\mathrm{II}}\left(\mathrm{CDA}-\mathrm{BPA}^{*}\right)\right]^{2+}(\mathbf{1 2})[50],\left[\mathrm{Mn}^{\mathrm{II}}(\mathrm{N} 4 \mathrm{Py} *)\left(\mathrm{CH}_{3} \mathrm{CN}\right)\right]^{2+}(\mathbf{5})$ [27], [Mn $\left.{ }^{\mathrm{II}}(\mathrm{Bn}-\mathrm{TPEN})\left(\mathrm{CH}_{3} \mathrm{CN}\right)\right]^{2+}(9)$ [49].

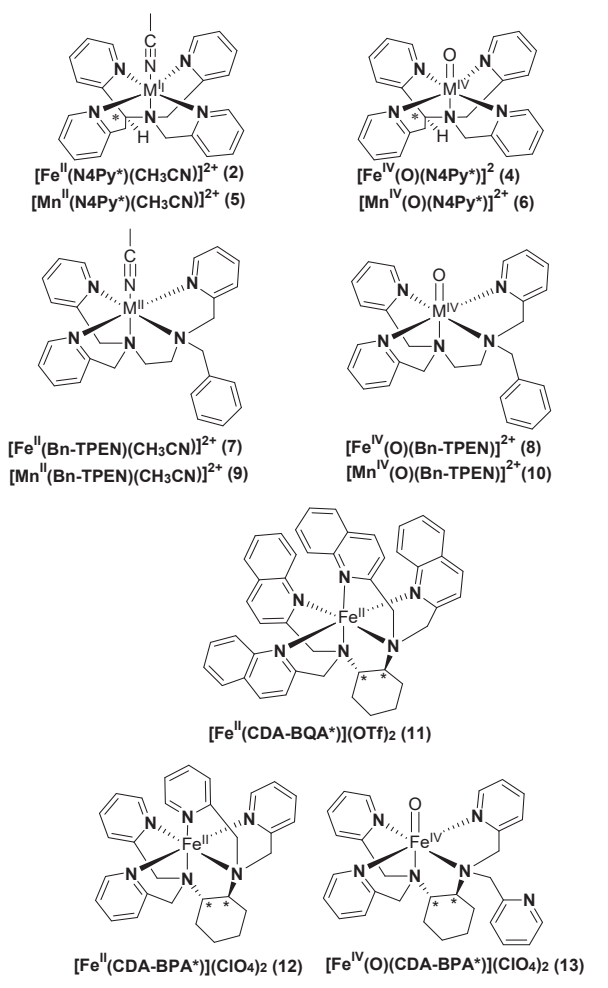

7. Ábra. Oxovas(IV) és oxomangán(IV) komplexek és a vas(II) és mangán(II) prekurzor komplexeik. [40] 
Az N4Py-típusú vas komplexek funkcionális flavon szintáz modellnek tekinthetők, mivel képesek a flavanon 2,3-deszaturációját végrehajtani 2-hidroxi-flavanon közbenső termék képződésén keresztül. Megpróbáltuk növelni a katalitikus aktivitást TPEN-típusú ligandumok alkalmazásával és vizsgáltuk a fém-kofaktor szerepét és hatását vas- és mangán komplexekkel ugyanazon ligandumkerettel. Összehasonlítva a $\left[\mathrm{Fe}^{\mathrm{IV}}(\mathrm{O})(\mathrm{Bn}-\mathrm{TPEN})\right]^{2+}$ (8) és $\left[\mathrm{Mn}^{\mathrm{IV}}(\mathrm{O})(\mathrm{Bn}-\mathrm{TPEN})\right]^{2+}(\mathbf{1 0})$ komplexek reakcióját flavanonnal ugyanazon körülmények között, 3,5-szer gyorsabban játszódott le a reakció a $\left[\mathrm{Fe}^{\mathrm{IV}}(\mathrm{O})\right.$ $(\mathrm{Bn}-\mathrm{TPEN})]^{2+}$ komplexszel. Az oxovas (IV) komplexek relatív reaktivitása: $\left[\mathrm{Fe}^{\mathrm{IV}}(\mathrm{O})\left(\mathrm{CDA}-\mathrm{BPA}^{*}\right)\right]^{2+}(\mathbf{1 2})>\left[\mathrm{Fe}^{\mathrm{IV}}(\mathrm{O})(\mathrm{Bn}-\right.$ TPEN) $]^{2+}(\mathbf{8})>\left[\mathrm{Fe}^{\mathrm{IV}}(\mathrm{O})(\mathrm{N} 4 \mathrm{Py})\right]^{2+}(\mathbf{2})>\left[\mathrm{Fe}^{\mathrm{IV}}(\mathrm{O})\left(\mathrm{N} 4 \mathrm{Py}{ }^{*}\right)\right]^{2+}(\mathbf{4})$ összhangban van a katalitikus eredményeinkkel, és azt mutatja, hogy a ciklohexán-diamin, mint királis elem hozzáadása a katalitikus aktivitás növekedéséhez vezet [27].

\section{Kétmagvú vastartalmú modellek}

A nem-hem divastartalmú enzimek nagyon változatos kémiai reakciók lejátszódásáért felelősek. Ezen enzimek csoportjába tartoznak a ribonukleotid reduktáz (RNR-R2), a sztearil-ACP $\Delta^{9}$ deszaturáz, az oldható metán-monooxigenáz (sMMO), a humán deoxihipuszin hidroxiláz (hDOHH), a hemeritrin (Hr) és az aldehid deformiláz oxigenáz (cADO), amelyek aktív centrumát a 8 . Ábrán tüntettük fel.
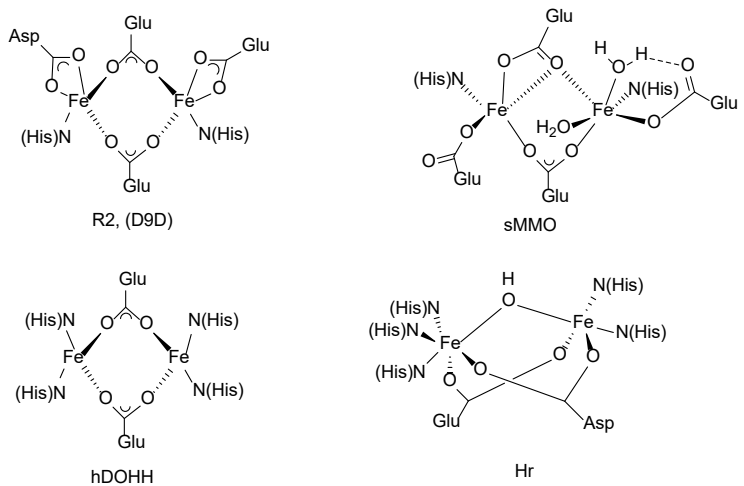

$\mathrm{Hr}$

8. Ábra. Divas(II) tartalmú enzimek aktív centruma

A ribonukleotid reduktáz a DNS bioszintézisének a kulcsfontosságú lépését katalizálja, a ribonukleotidok dezoxiribonukleotiddá alakítását [50]. A sztearil-ACP $\Delta^{9}$ deszaturáz egy cisz kettős kötés kialakításáért felel a sztearil ACP 9-es és 10es szénatomja között, mellyel oleoil-ACP-t eredményez [52]. A metán-monooxigenáz a metán metanollá történő szelektív oxidációját katalizálja a metanotróf baktériumokban [53]. A humán deoxihipuszin hidroxiláz a hipuszin bioszintézisében vesz részt és fontos szerepe van a sejtosztódásban, ezért új antitumor terápiák kidolgozását is elősegítheti az enzim által katalizált folyamatok megértése [54]. A hemeritrin az $\mathrm{O}_{2}$ felvételében és szállításában játszik kulcs szerepet [55]. Az aldehid deformiláz oxigenáz a hosszú alifás szénláncok bioszintézisét végzi a növényekben, rovarokban és egyes baktériumokban [56]. Ezen enzimek redukált formája dioxigénnel metastabilis intermediereket képez [51]: Hr enzim esetén egy $\mathrm{Fe}^{\mathrm{III}}\left(\mu-\mathrm{O}_{2} \mathrm{R}\right)(\mu-\mathrm{O}) \mathrm{Fe}^{\mathrm{III}} \mathrm{OOH}$ szerkezetű peroxidhoz jutunk, az R2, $\Delta^{9}$, sMMO és hDOHH enzimek esetén pedig egy $\mathrm{Fe}^{\mathrm{III}}\left(\mu-\mathrm{O}_{2}\right) \mathrm{Fe}^{\mathrm{III}}$ szerkezetü peroxidot kapunk.

Az irodalomból eddig megismert peroxo-divas(III) komplexek nagyon változatos szerkezettel írhatók le: $\mathrm{Fe}^{\mathrm{III}}\left(\mu-\mathrm{O}_{2}\right)$ $\mathrm{Fe}^{\mathrm{III}}, \mathrm{Fe}^{\mathrm{III}}(\mu-\mathrm{O})\left(\mu-\mathrm{O}_{2}\right) \mathrm{Fe}^{\mathrm{III}}, \mathrm{Fe}^{\mathrm{III}}(\mu-\mathrm{OH})\left(\mu-\mathrm{O}_{2}\right) \mathrm{Fe}^{\mathrm{III}}, \mathrm{Fe}^{\mathrm{III}}(\mu-$ $\mathrm{OR})\left(\mu-\mathrm{O}_{2}\right) \mathrm{Fe}^{\mathrm{III}}, \mathrm{Fe}^{\mathrm{III}}(\mu-\mathrm{OR})\left(\mu-\mathrm{OCR}^{\prime}\right)\left(\mu-\mathrm{O}_{2}\right) \mathrm{Fe}^{\mathrm{III}}$. Fe $\mathrm{Fe}^{\mathrm{II}}$ prekurzor és hidrogén peroxid reakciója során $\mathrm{Fe}^{\mathrm{III}}\left(\mu-\mathrm{O}_{2}\right) \mathrm{Fe}^{\mathrm{III}}$ összetételü szerkezetet kaphatunk.

Munkánk során relatív stabil peroxo-divas(III) komplexeket állítottunk elő a 9. Ábrán szereplő ligandumokból és az enzimreakciók során feltételezett intermedierek szerepét tisztáztuk.
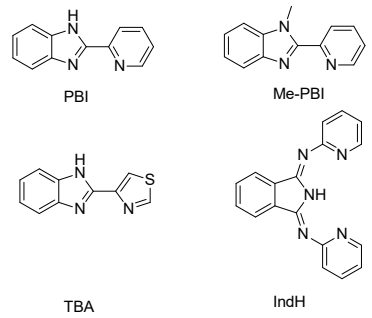

9. Ábra. Peroxo-divas(III) komplexek előállításához használt ligandumok

Két peroxo addukt $\left[\mathrm{Fe}_{2}\left(\mu-\mathrm{O}_{2}\right)(\mathrm{PBI})_{4}\left(\mathrm{CH}_{3} \mathrm{CN}\right)_{2}\right]^{2+}$, és $\left[\mathrm{Fe}_{2}\left(\mu-\mathrm{O}_{2}\right)(\mathrm{Me}-\mathrm{PBI})_{4}\left(\mathrm{CH}_{3} \mathrm{CN}\right)_{2}\right]^{2+},(\mathrm{PBI}=2$-(2'-piridil)benzimidazol Me-PBI $=2-\left(2^{\prime}\right.$-piridil $)-N$-metilbenzimidazol) reaktivitását figyeltük meg $\mathrm{H}_{2} \mathrm{O}_{2}$-dal kataláz modellként [57] és különböző fenolokkal funkcionális RNR-R2 modellként. A kinetikai és reakciómechanizmus vizsgálatok, valamint az elméleti számítások közvetlen bizonyítékot szolgáltattak arra, hogy a ( $\mu$-1,2-peroxo)-divas(III) köztitermék részt vesz az O-H aktivációs folyamatban alacsony spinü oxovas(IV) intermedier képződése révén [58].

A korábban közölt peroxo-adduktok $\left(\left[\mathrm{Fe}^{\mathrm{III}}{ }_{2}\left(\mu-\mathrm{O}_{2}\right)\left(\mu-1,2-\mathrm{O}_{2}\right)\right.\right.$ $\left.(\mathrm{MeBzim}-\mathrm{Py})_{4}\left(\mathrm{CH}_{3} \mathrm{CN}\right)_{2}\right]^{2+} \quad \mathrm{MeBzim}-\mathrm{Py}=2-\left(2^{\prime}\right.$-piridil)- $N$-metilbenzimidazol $\quad[59], \quad\left[\mathrm{Fe}_{2}^{\mathrm{III}}(\mu-\mathrm{O})\left(\mu-1,2-\mathrm{O}_{2}\right)\right.$ $\left.(\mathrm{IndH})_{2}\left(\mathrm{CH}_{3} \mathrm{CN}\right)_{2}\right]^{2+}($ IndH $=1,3$-bisz (2- piridil-imino) izoindolin) [60]) reaktivitását tanulmányoztuk nukleofil (pl. alkil- és aril-alkil-aldehidek deformilezése) és elektrofil (pl. fenolok, $\mathrm{H}_{2} \mathrm{O}_{2}$ oxidációja) sztöchiometrikus reakciókban (10. Ábra), mint RNR-R2, cADO és kataláz enzimek modelljeit (2. Táblázat). Részletes kinetikai és reakciómechanizmus vizsgálatok alapján további bizonyítékokat találtunk a peroxo intermedierek ambifil viselkedésére, amelyet a divastartalmú oxidoreduktáz enzimekre javasolnak.

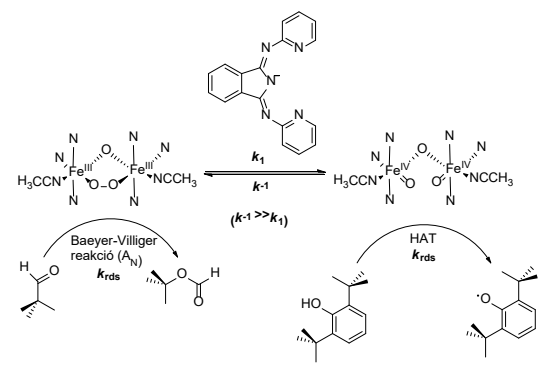

10. Ábra. A $\left[\mathrm{Fe}_{2}^{\mathrm{III}}{ }_{2}(\mu-\mathrm{O})\left(\mu-1,2-\mathrm{O}_{2}\right)(\mathrm{IndH})_{2}\left(\mathrm{CH}_{3} \mathrm{CN}\right)_{2}\right]^{2+}$ elektrofil (fenol oxidáció) és nukleofil (aldehid deformilezés) reakciója. 


\begin{tabular}{lllllll}
\hline szubsztrátum & komplex & $\begin{array}{l}k_{2} \\
{\left[\mathrm{M}^{-1} \mathrm{~s}^{-1}\right]^{\mathrm{a}}}\end{array}$ & $\begin{array}{l}\Delta H^{\ddagger} \\
{\left[\mathrm{kJmol}^{-1}\right]}\end{array}$ & $\begin{array}{l}\Delta S^{\ddagger} \\
{\left[\mathrm{Jmol}^{-1} \mathrm{~K}^{-1}\right]}\end{array}$ & $\begin{array}{l}\Delta G^{\ddagger} \\
{\left[\mathrm{kJmol}^{-1}\right]}\end{array}$ & Hivatkozás \\
\hline trimetil-acetaldehid & 1 & $2,96 \pm 0,15$ & $21 \pm 1$ & $-163 \pm 3$ & $69 \pm 2$ & {$[54]$} \\
ciklohexán-karboxaldehid & 1 & $2,34 \pm 0,10$ & $27 \pm 1$ & $-144 \pm 5$ & $69 \pm 3$ & {$[54]$} \\
ciklohexán-karboxaldehid & 2 & 0,192 & 67 & -18 & 72 & {$[53]$} \\
benzaldehid & 1 & $2,39 \pm 0,06$ & $28 \pm 1$ & $-138 \pm 3$ & $69 \pm 2$ & {$[54]$} \\
benzaldehid & 2 & 0,59 & 42 & -98 & 71 & {$[53]$} \\
fenilacetaldehid & 1 & $0,95 \pm 0,06$ & $18 \pm 1$ & $-181 \pm 2$ & $72 \pm 1$ & {$[54]$} \\
fenilacetaldehid & 2 & 0,04 & 52 & -87 & 77 & {$[53]$} \\
propionaldehid & 1 & $0,77 \pm 0,03$ & $29 \pm 2$ & $-145 \pm 6$ & $72 \pm 4$ & {$[54]$} \\
propionaldehid & 2 & 0,074 & 52 & -92 & 78 & {$[53]$} \\
2-fenil-propionaldehid & 1 & $0,68 \pm 0,04$ & $25 \pm 1$ & $-162 \pm 5$ & $73 \pm 2$ & {$[54]$} \\
2-fenil-propionaldehid & 2 & 0,002 & 72 & -34 & 82 & {$[53]$} \\
2,6-di-terc-butilfenol & 1 & $0,40 \pm 0,01$ & $27 \pm 4$ & $-175 \pm 14$ & $79 \pm 8$ & {$[54]$} \\
2,6-di-terc-butilfenol & 2 & & 64 & -108 & 96 & {$[53]$} \\
\hline
\end{tabular}

${ }^{a}$ Acetonitrilben, $10^{\circ} \mathrm{C}$-on.

2. Táblázat. A kapott reakciósebességi állandó értékek és a számított aktiválási paraméterek a peroxo-vas(III) komplexek aldehidekkel és fenolokkal történő reakciója során.

A $\left[\mathrm{Fe}^{\mathrm{II}}(\mathrm{TBA})_{3}\left(\mathrm{CH}_{3} \mathrm{SO}_{3}\right)_{2}\right](\mathrm{TBA}=2$-(4-tiazolil) benzimidazol) komplexből hidrogén-peroxiddal képeztük a $\left[\mathrm{Fe}_{2}^{\mathrm{III}}\left(\mu-\mathrm{O}_{2}\right)(\mathrm{TBA})_{4}\left(\mathrm{CH}_{3} \mathrm{CN}\right)_{2}\right]_{4}$ komplexet, amely az oxidoreduktáz enzimek katalitikus ciklusa során keletkezett peroxo divas intermedierek funkcionális modellje [61]. A komplex spektroszkópiai tulajdonságai összhangban vannak az $N$-donor ligandumokkal képzett komplexek tulajdonságaival. Ez a komplex elektrofil és nukleofil reaktivitást is mutat az $\mathrm{O}-\mathrm{H}$ kötések $\left(\mathrm{H}_{2} \mathrm{O}_{2}\right.$, fenolok) oxidációjában, az aldehidek deformilezésében és a DMA oxidatív $N$-demetilezésében elektrofil C-H aktiváláson keresztül.

\section{Összefoglalás}

Az egymagvú, nem-hem, vastartalmú enzimek modellezésére előállítottunk két Fe(II) komplexet és oxovas(IV) komplexeiket, amelyek reaktivitását vizsgáltuk OAT és HAT reakciókban. A királis komplexszel enantioszelektív reakciókban magas ee értékeket értünk el. Az általunk készített N4Py-típusú vas komplexek funkcionális flavon szintáz modellnek tekinthetők. Az oxovas (IV) komplexek relatív reaktivitását meghatároztuk: $\left[\mathrm{Fe}^{\mathrm{IV}}(\mathrm{O})\left(\mathrm{CDA}-\mathrm{BPA}{ }^{*}\right)\right]^{2+}$ (12) $>\left[\mathrm{Fe}^{\mathrm{IV}}(\mathrm{O})(\mathrm{Bn}-\mathrm{TPEN})\right]^{2+}(\mathbf{8})>\left[\mathrm{Fe}^{\mathrm{IV}}(\mathrm{O})(\mathrm{N} 4 \mathrm{Py})\right]^{2+}$ (2) > $\left[\mathrm{Fe}^{\mathrm{IV}}(\mathrm{O})(\mathrm{N} 4 \mathrm{Py})^{*}\right]^{2+}$ (4). Majd az oxovas(IV) komplexek mintájára oxomangán(IV) intermedierekkel is tanulmányoztuk flavanon sztöchiometrikus és katalitikus oxidációs reakcióját. Végül relatív stabil peroxo-divas(III) komplexeket állítottunk elö, amelyekből képzett peroxo intermedierek reaktivitását analizáltuk $\mathrm{H}_{2} \mathrm{O}_{2}$-dal kataláz modellként, különböző fenolokkal funkcionális RNR R2 modellként és különböző aldehidekkel funkcionális cADO modellként. Részletes kinetikai vizsgálatok alapján bizonyítékokat találtunk a peroxo intermedierek ambifil viselkedésére, tehát elektrofil és nukleofil reaktivitást is mutatnak.

\section{Köszönetnyilvánítás}

A kutatás az Országos Tudományos Kutatási Alapprogram (OTKA K108489), a GINOP-2.3.2-15-2016-00049, TÁMOP4.2.2.B-15/1/KONV-2015-0004, az Emberi Erőforrások Minisztériuma Új Nemzeti Kiválóság Programja (2016-3IV. Lakk-Bogáth Dóra) és a TKP2020-IKA-07 finanszírozásával valósult meg.

\section{Hivatkozások}

1. Körös, E., Bioszervetlen kémia, Gondolat Kiadó, Budapest 1980.

2. Taabazuing, C. Y.; Hangsky, J. A.; Knapp, M. J. J. Inorg. Biochem. 2014, 133, 63-72.

https://doi.org/10.1016/j.jinorgbio.2013.12.010.

3. Shen, L.; Song, C.-X.; He, C.; Zhang Y. Annu. Rev. Biochem. 2014, 83, 585-614. https://doi.org/10.1146/annurev-biochem-060713-035513

4. Mosammaparast, N.; Shi Y. Annu. Rev. Biochem. 2010, 79, 155-179.

https://doi.org/10.1146/annurev.biochem.78.070907.103946

5. Gorres, K. L.; Raines, R. T. Crit. Rev. Biochem. Mol. Biol. 2010, 45, 106-124.

https://doi.org/10.3109/10409231003627991

6. Hausinger, R. P. Crit. Rev. Biochem. Mol. Biol. 2004, 39, 21-68.

https://doi.org/10.1080/10409230490440541

7. Hamed, R. B.; Gomez-Castellanos, J. R.; Henry, L.; Ducho, C.; McDonough, M. A.; Schofield, C. J. Nat. Prod. Rep. 2013, 30, 21-107.

https://doi.org/10.1039/C2NP20065A

8. Price, J. C.; Barr, E. W.; Tirupati, B.; Bollinger, J. M.; Krebs, C. Biochemistry 2003, 42, 7497-7508. https://doi.org/10.1021/bi030011f 
9. Sinnecker, S.; Svensen, N.; Barr, E. W.; Ye, S.; Bollinger, J. M.; Neese, F.; Krebs, C. J. Am. Chem. Soc. 2007, 129, 6168-6179. https://doi.org/10.1021/ja067899q

10. Riggs-Gelasco, P. J.; Price, J. C.; Guyer, R. B.; Brehm, J. H.; Barr, E. W.; Bollinger, J. M.; Krebs, C. J. Am. Chem. Soc. 2004, 126, 8108-8109. https://doi.org/10.1021/ja048255q

11. Price, J. C.; Barr, E. W.; Glass, T. E.; Krebs, C.; Bollinger, J. M. J. Am. Chem. Soc. 2003, 125, 13008-13009. https://doi.org/10.1021/ja0263137

12. Hoffart, L. M.; Barr, E. W.; Guyer, R. B.; Bollinger, J. M.; Krebs C. Proc. Natl. Acad. Sci. 2006, 103, 14738-14743. https://doi.org/10.1073/pnas.0604005103

13. Chang, W.; Guo, Y.; Wang, C.; Butch, S. E.; Rosenzweig, A. C.; Boal, A. K.; Krebs, C.; Bollinger, J. M. Science 2014, $343,1140-1144$. https://doi.org/10.1126/science.1248000

14. Ryle, M. J.; Padamkumar, R.; Hausinger, R. P. Biochemistry 1999, 38, 15278-15286. https://doi.org/10.1021/bi9912746

15. Costas, M.; Mehn, M. P.; Jensen, M. P.; Que, L. Jr. Chem. Rev. 2004, 104, 939-986. https://doi.org/10.1021/cr020628n

16. Adam, D. O.; Yang, S. F. PNAS 1979, 76, 170-174. https://doi.org/10.1073/pnas.76.1.170

17. Dong, J. G.; Fernandez-Maculet, J. C.; Yang, S. F. PNAS 1992, 89, 9789-9793. https://doi.org/10.1073/pnas.89.20.9789

18. Peiser, G. D.; Wang, T. T.; Hoffman, N. E.; Yang, S. F.; Liu, H. W.; Walsh, C. T. PNAS 1984, 81, 3059-3063. https://doi.org/10.1073/pnas.81.10.3059

19. Lakk-Bogáth, D.; Speier, G.; Kaizer, J. NJC 2015, 39, $8245-8248$. https://doi.org/10.1039/C5NJ02093J

20. Lakk-Bogáth, D.; Speier G.; Kaizer J. Polyhedron 2018, 145, 227-230. https://doi.org/10.1016/j.poly.2018.02.015

21. Turcas, R.; Lakk-Bogáth, D.; Speier, G.; Kaizer J. Dalton Trans. 2018, 47, 3248-3252. https://doi.org/10.1039/C7DT03727A

22. Lakk-Bogáth, D.; Csonka, R.; Speier, G,; Réglier, M.; Simaan, A. J.; Naubron, J.-V.; Giorgi, M.; Lázár, K.; Kaizer, J. Inorg. Chem. 2016, 55 (20), 10090-10093. https://doi.org/10.1021/acs.inorgchem.6b01089

23. Turcas, R.; Lakk-Bogáth, D.; Speier, G.; Kaizer, J. Inorg. Chem. Commun. 2018, 92, 141-144. https://doi.org/10.1016/j.inoche.2018.04.024

24. Lakk-Bogáth, D.; Kripli, B.; Meena, B. I.; Speier, G.; Kaizer, J. Inorg. Chem. Comm. 2019, 104, 165-170. https://doi.org/10.1016/j.inoche.2019.04.008

25. Meena, B. I.; Lakk-Bogáth, D.; Kripli, B.; Speier, G.; Kaizer, J. Polyhedron 2018, 151, 141-145. https://doi.org/10.1016/j.poly.2018.05.044

26. Meena, B. I.; Kaizer, J. Catalysts 2020, 10, 404. https://doi.org/10.3390/catal10040404

27. Kripli, B.; Garda, Z.; Sólyom, B.; Tircsó, G.; Kaizer, J. NJC 2020, 44, 5545-5555. https://doi.org/10.1039/C9NJ06004A

28. Kripli, B.; Sólyom, B.; Speier, G.; Kaizer, J. Molecules 2019, 24, 3236-3267. https://doi.org/10.3390/molecules24183236

29. Singh, M.; Kaur, M.; Silakari, O. Eur. J. Med. Chem. 2014, 84, 206-239. https://doi.org/10.1016/j.ejmech.2014.07.013

30. Ko, T.P.; Day, J.; Malkin, A.J.; McPherson, A. Acta Crystallogr. 1999, 55, 1383-1394. https://doi.org/10.1107/S0907444999007052
31. Martens, S.; Forkmann, G. Phytochemistry 1998, 49,19531958. https://doi.org/10.1016/S0031-9422(98)00345-8

32. Akashi, T.; Aoki, T.; Ayabe, S.I. Plant Physiol. 1999, 121, 821-828. https://doi.org/10.1104/pp.121.3.821

33. Akashi, T.; Aoki, T.; Ayabe, S.I. FEBS Lett. 1998, 431, 287-290. https://doi.org/10.1016/S0014-5793(98)00781-9

34. Zhang, J.; Subramanian, S.; Zhang, Y.; Yu, O. Plant Physiol. 2007, 144, 741-751. https://doi.org/10.1104/pp.106.095018

35. Du, Y.; Chu, H.;Wang, M.; Chu, I.K.; Lo, C. J. Exp. Bot. 2010, 61, 983-994. https://doi.org/10.1093/jxb/erp364

36. Kappock, T. J.; Caradonna, J. P. Chem. Rev. 1996, 96, $2659-2756$. https://doi.org/10.1021/cr9402034

37. Elkins, J. M.; Ryle, M. J.; Clifton, I .J.; Dunning Hottop, J. C.; Lloyd, J. S.; Burzlaff, N. I.; Baldwin, J. E.; Hausinger, R. P.; Roach, P. L. Biochemistry 2002, 41, 5185-5192. https://doi.org/10.1021/bi016014e

38. Costas, M.; Mehn, M. P.; Jensen, M. P.; Que, L., Jr. Chem. Rev. 2004, 104, 939-986. https://doi.org/10.1021/cr020628n

39. Nam,W. Acc. Chem. Res. 2007, 40, 465. https://doi.org/10.1021/ar700131d

40. Gebhardt, Y.; Witte, S.; Forkmann, G.; Lukacin, R.; Matern, U.; Martens, S Phytochemistry 2005, 66, 1273-1284. https://doi.org/10.1016/j.phytochem.2005.03.030

41. Gebhardt, Y. H.; Witte, S.; Steuber, H.; Matern, U.; Martens, S. Plant Physiol. 2007, 144, 1442-1454. https://doi.org/10.1104/pp.107.098392

42. Lee, Y. J.; Kim, J. H.; Kim, B. G.; Lim, Y.; Ahn, J. H. $B M B$ Rep. 2008, 41, 68-71. https://doi.org/10.5483/BMBRep.2008.41.1.068

43. Britsch, L. Arch. Biochem. Biophys. 1990, 282, 152-160. https://doi.org/10.1016/0003-9861(90)90099-K

44. Hanauske-Abel, H. M.; Günzler, V.; J. Theor. Biol. 1982, 94 , 421-455. https://doi.org/10.1016/0022-5193(82)90320-4

45. Du, Y.; Chu, H.; Chu, I. K.; Lo, C. Plant Physiol. 2010, 154, 324-333. https://doi.org/10.1104/pp.110.161042

46. Lakk-Bogáth, D.; Juraj, N. P.; Meena, B. I.; Peric, B.; Kirin, S. I.; Kaizer, J. Molecules 2021, 26 (11) 3220-3235. https://doi.org/10.3390/molecules26113220

47. Kaizer, J.; Klinker, E. J.; Oh, N. Y.; Rohde, J.-U.; Song,W. J.; Stubna, A.; Kim, J.; Münck, E.; Nam,W.; Que, L., Jr. J. Am. Chem. Soc. 2004, 126, 472-473. https://doi.org/10.1021/ja037288n

48. Klinker, E. J.; Kaizer, J.; Brennessel, W. B.; Woodrum, N. L.; Cramer, C.J.; Que, L., Jr. Angew. Chem. 2005, 117, 3756-3760. https://doi.org/10.1002/anie.200500485

49. Wu, X.; Seo, M.S.; Davis, K.M.; Lee, Y.-M.; Chen, J.; Cho, K.-B.; Pushkar, Y.N.; Nam, W. J. Am. Chem. Soc. 2011, 133, 20088-20091. https://doi.org/10.1021/ja208523u

50. McCuster, J. K.; Toftlund, H.; Rheingold, A. L.; Hendrickson, D. N. J. Am. Chem. Soc. 1993, 115, 1797-1804 https://doi.org/10.1021/ja00058a026

51. Bois, J. D.; Mizoguchi, T. J.; Lippard, S. J. Cord.Chem. Rev. 2000, 200-202, 443-485. https://doi.org/10.1016/S0010-8545(00)00336-2

52. Solomon, E. I.; Brunold, T.; Davis, M. I.; Kemsley, J.; S. Lee, K.; Lehnert, N.; Neese, F.; Skulan, A. J.; Yang, Y. S.; Zhou J. Chem. Rev. 2000, 100, 235-350. https://doi.org/10.1021/cr9900275 
53. Rosenzweig, A.C.; Lippard, S. J. Acc. Chem. Res. 1994, 27 , 229-236. https://doi.org/10.1021/ar00044a003

54. Vu, V. V.; Emerson, J. P.; Martinho, M.; Kim, Y. S.; Münck, E.; Park, M. H.; Que, L. Jr. PNAS 2009, 106, 14814-14819. https://doi.org/10.1073/pnas.0904553106

55. Kurtz, D. M. Jr.; Shriver, D. F.; Klotz, I. M. Coord. Chem. Rev. 1977, 24, 145-178. https://doi.org/10.1016/S0010-8545(00)80337-9

56. Schirmer, A.; Rude, M. A.; Li, X.; Popova, E.; del Cardayre, S. B. Science 2010, 329, 559-562. https://doi.org/10.1126/science.1187936

57. Lakk-Bogáth, D.; Török, P.; Csendes, F. V.; Keszei, S.; Gantner, B.; Kaizer, J. Molecules 2021, 26, 4501. https://doi.org/10.3390/molecules26154501
58. Szávuly, M. I.; Surducan, M.; Nagy, E.; Surányi, M.; Speier, G.; Silaghi-Dumitrescu, R.; Kaizer, J. Dalton Trans. 2016, $45,14709-14718$. https://doi.org/10.1039/C6DT01598K

59. Kripli, B.; Csendes, F. V.; Török, P.; Speier, G.; Kaizer, J. Chemistry- A European Journal 2019, 25, 14290-14294. https://doi.org/10.1002/chem.201903727

60. Kripli, B.; Szávuly, M.; Csendes, F. V.; Kaizer, J. Dalton Trans. 2020, 49, 1742.1746. https://doi.org/10.1039/C9DT04551A

61. Török, P.; Unjaroen, D.; Csendes, F. V.; Giorgi, M.; Browne, W. R.; Kaizer, J. Dalton Trans. 2021, 50, 7181-7185. https://doi.org/10.1039/D1DT01502H

\section{Investigation of biomimetic reactions of oxidoreductase enzymes}

The mechanism of reactions catalyzed by metalloenzymes has been long studied in chemistry and biology. Enzymes, the purity of which is not always satisfactory, can be recovered from the body by a difficult, complicated process. The structure of the active site is not yet known in most cases, and synthetic modeling is a well-established method to overcome these problems. Enzyme models can basically be divided into two groups: structural and functional models [1]. Structural models facilitate the understanding of the spatial structure of the active site by comparing the spectroscopic data of the models and the enzymes. Functional models help to understand the mechanism of enzyme-catalyzed reactions and allow the development of artificial catalytic systems.

The largest and most diverse family of mononuclear non-heme iron-containing enzymes (Figure 1) are those ones that contain an $\alpha$-keto acid as a cosubstrate. These enzymes can perform a number of transformations, such as hydroxylation, desaturation, epimerization, heterocyclic ring formation and ring coupling, epoxidation, and halogenation. These enzymes also play a role in a number of important biological processes: cellular oxygen sensing [2], DNA and RNA repair [3], histone demethylation during epigenetic regulation [4], and posttranslational modification of amino acid side chains of various proteins $[2 ; 5 ; 6]$ and in the biosynthesis of antibiotics [7].

To model mononuclear non-heme iron-containing enzymes, the following complexes and oxoiron(IV) intermediates (Figure 4) were prepared: $\left[\mathrm{Fe}^{\mathrm{II}}(\mathrm{N} 4 \mathrm{Py})\left(\mathrm{CH}_{3} \mathrm{CN}\right)\right]\left(\mathrm{ClO}_{4}\right)_{2}(\mathrm{~N} 4 \mathrm{Py}=N, N$-bis (2-pyridyl(methyl)bis(2-pyridyl)methylamine) (1), [Fe ${ }^{\mathrm{II}}(\mathrm{N} 4 \mathrm{Py} *)$ $\left.\left(\mathrm{CH}_{3} \mathrm{CN}\right)\right]\left(\mathrm{ClO}_{4}\right)_{2}(\mathrm{~N} 4 \mathrm{Py} *=N, N$-bis(2-pyridylmethyl) $) N$-bis $(2-$ pyridyl) methylamine) (2), $\left[\mathrm{Fe}^{\mathrm{IV}}(\mathrm{O})(\mathrm{N} 4 \mathrm{Py})\right]^{2+}(\mathbf{3}),\left[\mathrm{Fe}^{\mathrm{IV}}(\mathrm{O})\right.$ $\left.\left(\mathrm{N} \mathrm{Py} \mathrm{y}^{*}\right)\right]^{2+}(4)$. The efficiency and reactivity of the complexes were investigated in oxygen atom transfer (OAT) and hydrogen atom transfer (HAT) reactions, and we tried to develop enantioselective reactions with the chiral iron complex. During the oxidation of thioanisole derivatives we achieved high enantioselectivity values $64-96 \%$ [19], during the oxidation of cyclohexanone derivatives $30-45 \%$ [20], during the oxidation of ethylbenzene $13-33 \%$ [21], and during the oxidation of styrene derivatives $8-12 \%$ ee values were achieved [22] (Table 1).

Flavonoids are low molecular weight polyphenolic phytochemical materials. They are derived from the secondary metabolism of plants and play an important role in various biological processes. They are involved in the color formation of plants, UV protection, plant protection, and interactions between species. Due to their broad-spectrum biological activity, their syntheses have become an important target for pharmaceutical chemists and bioorganic chemists [23]. One of the most important steps in the biosynthesis of flavones is the oxidation of flavanones by heme and non-heme iron-dependent enzymes. The high valence oxoiron(IV) intermediates are key oxidants in both heme and non-heme enzymes, e.g., cytochrome P450 [24], flavone synthase II (FSII) [25; 26; 27; 28; 29], pterin-dependent phenylalanine hydroxylase [30] and $\alpha$-keto acid-dependent dioxygenases (taurine dioxygenase, TauD [31-33] and flavone synthase I, FS I [34-37]. Stoichiometric and catalytic flavanone oxidation reactions were studied with spectroscopically well-characterized non-heme oxoiron (IV) intermediates and oxomanganese (IV) intermediates [40]. $\left[\mathrm{Fe}^{\mathrm{IV}}(\mathrm{O})(\mathrm{Bn}-\mathrm{TPEN})\right]^{2+}$ (8) $[41 ; 42],\left[\mathrm{Fe}^{\mathrm{IV}}(\mathrm{O})(\mathrm{CDA}-\mathrm{BPA})\right]^{2+}(\mathbf{1 1}),\left[\mathrm{Mn}^{\mathrm{IV}}(\mathrm{O})(\mathrm{N} 4 \mathrm{Py} *)\right]^{2+}$ (6) [43], $\left[\mathrm{Mn}^{\mathrm{IV}}(\mathrm{O})(\mathrm{Bn}-\mathrm{TPEN})\right]^{2+}(\mathbf{1 0})$ [44] and their prekursor complexes, $\left[\mathrm{Fe}^{\mathrm{II}}(\mathrm{Bn}-\mathrm{TPEN})\left(\mathrm{CH}_{3} \mathrm{CN}\right)\right]^{2+}(\mathbf{7}),\left[\mathrm{Fe}^{\mathrm{II}}\left(\mathrm{CDA}-\mathrm{BQA}^{*}\right)\right]^{2+}(\mathbf{1 1})$, $\left[\mathrm{Fe}^{\mathrm{II}}\left(\mathrm{CDA}-\mathrm{BPA}^{*}\right)\right]^{2+}(\mathbf{1 2})[45],\left[\mathrm{Mn}^{\mathrm{II}}(\mathrm{N} 4 \mathrm{Py})\left(\mathrm{CH}_{3} \mathrm{CN}\right)\right]^{2+}$ (5) [43], $\left[\mathrm{Mn}^{\mathrm{II}}(\mathrm{Bn}-\mathrm{TPEN})\left(\mathrm{CH}_{3} \mathrm{CN}\right)\right]^{2+}(9)$ (Figure 7) [44]. N4Py-type iron complexes can be considered as a functional flavone synthase model because of their ability to perform 2,3-desaturation of flavanone through the formation of a 2-hydroxy-flavanone intermediate. We tried to increase the catalytic activity using TPENtype ligands and investigated the role and effect of the metal cofactor with iron and manganese complexes with the same ligand framework. Relative reactivity of oxoiron(IV) complexes: $\left[\mathrm{Fe}^{\mathrm{IV}}(\mathrm{O})\left(\mathrm{CDA}-\mathrm{BPA}^{*}\right)\right]^{2+}(\mathbf{1 2})>\left[\mathrm{Fe}^{\mathrm{IV}}(\mathrm{O})(\mathrm{Bn}-\mathrm{TPEN})\right]^{2+}(\mathbf{8})>\left[\mathrm{Fe}^{\mathrm{IV}}(\mathrm{O})\right.$ $\mathrm{N} 4 \mathrm{Py})]^{2+}(\mathbf{2})>\left[\mathrm{Fe}^{\mathrm{IV}}(\mathrm{O})\left(\mathrm{N}_{4} \mathrm{Py}^{*}\right)\right]^{2+}(\mathbf{4})$, which is in agreement with our catalytic results and shows that the addition of cyclohexanediamine leads to an increase in catalytic activity [40].

Non-heme diiron-containing enzymes are responsible for a wide variety of chemical reactions. These enzymes include ribonucleotide reductase (RNR R2), stearyl-ACP $\Delta 9$-desaturase, soluble methane monooxygenase (sMMO), human deoxyhypusine hydroxylase $(\mathrm{hDOHH})$, hemeritrine $(\mathrm{Hr})$, and cyanobacterial aldehyde deformylase oxygenase (Figure 8). The reactivity of two peroxo adducts $\left[\mathrm{Fe}_{2}\left(\mu-\mathrm{O}_{2}\right)(\mathrm{PBI})_{4}\left(\mathrm{CH}_{3} \mathrm{CN}\right)_{2}\right]^{2+}$ and $\left[\mathrm{Fe}_{2}\left(\mu-\mathrm{O}_{2}\right)\right.$ $\left.(\mathrm{Me}-\mathrm{PBI})_{4}\left(\mathrm{CH}_{3} \mathrm{CN}\right)_{2}\right]^{2+},\left(\mathrm{PBI}=2-\left(2^{\prime}\right.\right.$-pyridyl $)$ benzimidazole MePBI $=2-\left(2^{\prime}\right.$-pyridyl $)-N$-methylbenzimidazole $)$ was investigated with $\mathrm{H}_{2} \mathrm{O}_{2}$ as a catalase model and with different phenols as a functional RNR R2 model. Kinetic, mechanical, and computational studies provided direct evidence that the ( $\mu-1,2-$ peroxo)-diiron(III) intermediate is involved in the $\mathrm{O}-\mathrm{H}$ activation process through the formation of a low-spin oxoiron (IV) species [52]. The reactivity of previously reported peroxo adducts $\left(\left[\mathrm{Fe}^{\mathrm{III}}{ }_{2}\left(\mu-\mathrm{O}_{2}\right)\left(\mu-1,2-\mathrm{O}_{2}\right)(\mathrm{MeBzim}-\mathrm{Py})_{4}\left(\mathrm{CH}_{3} \mathrm{CN}\right)_{2}\right]^{2+} \mathrm{MeBzim}-\mathrm{Py}=\right.$ 2-(2'-pyridyl)- $N$-methylbenzimidazole [53], $\left[\mathrm{Fe}^{\mathrm{III}}{ }_{2}(\mu-\mathrm{O})\left(\mu-1,2-\mathrm{O}_{2}\right)\right.$ $\left.(\text { IndH })_{2}\left(\mathrm{CH}_{3} \mathrm{CN}\right)_{2}\right]^{2+}$ (IndH $=1,3$-bis(2-pyridyl-imino)isoindoline) [54]) were studied in nucleophilic (e.g., deformylation of alkyl and arylalkyl aldehydes) and electrophilic (e.g., oxidation of phenols) stoichiometric reactions as models of RNR-R2 and cADO enzymes (Table 2). Based on detailed kinetic and mechanical studies, we found further evidence for the ambiphilic behavior of peroxo intermediates. We report the formation of the 
peroxo-diiron(III) species $\left[\mathrm{Fe}^{\mathrm{III}}{ }_{2}\left(\mu-\mathrm{O}_{2}\right)(\mathrm{TBA})_{4}\left(\mathrm{CH}_{3} \mathrm{CN}\right)_{2}\right]^{4+}$ from the $N$-heterocyclic ligand, 2-(4-thiazolyl)benzimidazole ligand (TBA) (Figure 9) [55]. This complex shows electrophilic and nucleophilic reactivity in the oxidation of $\mathrm{O}-\mathrm{H}$ bonds $\left(\mathrm{H}_{2} \mathrm{O}_{2}\right.$, phenols), aldehyde deformylation, and oxidative $N$-demethylation of DMA via electrophilic $\mathrm{C}-\mathrm{H}$ activation. The broad range of reactivity makes the complex a good functional model for diiron oxidoreductase enzymes.

In summary: To model mononuclear, non-heme, iron-containing enzymes, we prepared two Fe (II) complexes and their oxoiron(IV) complexes, the reactivity of which was investigated in OAT and HAT reactions. High ee values were obtained in enantioselective reactions with the chiral complex. The N4Py-type iron complexes produced by us can be considered as a functional flavon synthase model. The relative reactivity of oxoiron(IV) complexes was determined: $\left[\mathrm{Fe}^{\mathrm{IV}}(\mathrm{O})\left(\mathrm{CDA}-\mathrm{BPA}^{*}\right)\right]^{2+}(\mathbf{1 2})>\left[\mathrm{Fe}^{\mathrm{IV}}(\mathrm{O})\right.$ $(\mathrm{Bn}-\mathrm{TPEN})]^{2+}(\mathbf{8})>\left[\mathrm{Fe}^{\mathrm{IV}}(\mathrm{O})(\mathrm{N} 4 \mathrm{Py})\right]^{2+}(\mathbf{2})>\left[\mathrm{Fe}^{\mathrm{IV}}(\mathrm{O})(\mathrm{N} 4 \mathrm{Py} *]^{2+}(\mathbf{4})\right.$ Then, the stoichiometric and catalytic oxidation reactions of flavanone were also studied with oxomanganese (IV) intermediates for the sample of oxoiron (IV) complexes. Finally, relatively stable peroxo-diiron (III) complexes were prepared, from which the reactivity of peroxo intermediates formed was investigated with $\mathrm{H}_{2} \mathrm{O}_{2}$ as a catalase model, with different phenols as functional RNR R2 model, and with different aldehydes as functional cADO model. Based on detailed kinetic studies, we found evidence for the ambiphilous behavior of peroxo intermediates, so they also show electrophilic and nucleophilic reactivity. 